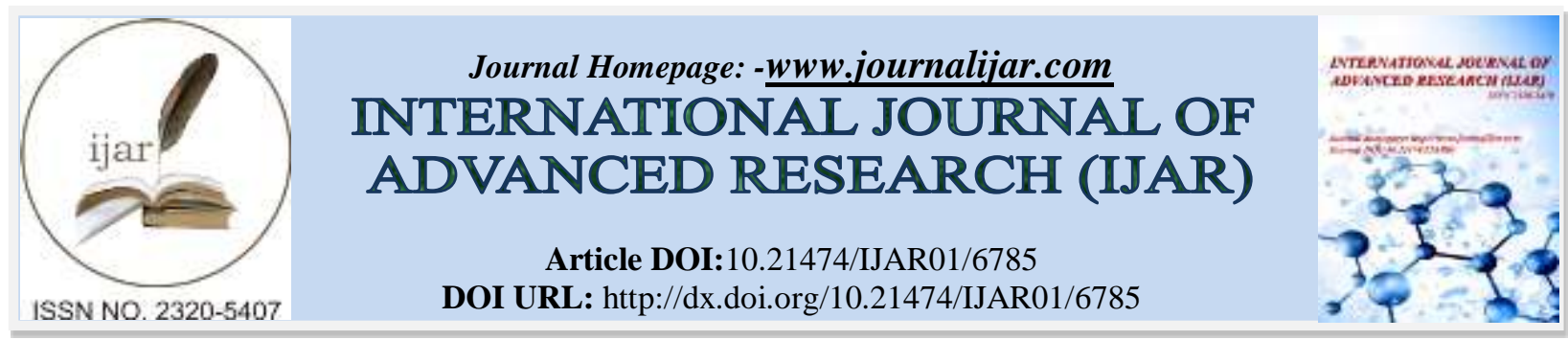

RESEARCH ARTICLE

\title{
FACILE DISINFECTION OF RIVER AND POND WATER USING NATURAL SOLAR RADIATION AT SHOA ROBIT AND NEIGHBORING RURAL KEBELES.
}

\section{Neway Belachew ${ }^{1}$, Solomon Mulaw ${ }^{1}$, Haftu G/Tsadik ${ }^{1}$, and Mebrahtu Hagos ${ }^{2}$.}

1. Debre Berhan University, Department of Chemistry, Debre Berhan, 445, Ethiopia.

2. Department of Inorganic \& Analytical Chemistry, Andhra University, Visakhapatnam-530003, India.

\section{Manuscript Info}

Manuscript History

Received: 19 January 2018

Final Accepted: 21 February 2018

Published: March 2018

Keywords:-

Solar disinfection; Water treatment,

PET, Turbidity, solar radiation.

\begin{abstract}
In this study, disinfection of water using a simple and green approach using natural Solar Radiation Disinfection (SODIS) techniques has been investigated. The water samples in a colorless polyethylene plastic were irradiated with solar radiation. The reduction of Total Coliform (TC) using solar radiation further investigated by introducing aluminum foils and mirrors as activators for the sterilization of TC. The raw water samples were obtained from local municipal drinking water and ponds in Shoa Robit and the surrounding rural areas. The total coliform reduction potential of SODIS results $99.9 \%$ decontamination at the end of six hours. Moreover, the results were showed that the disinfection process succeeded at the end of six hours using either of activators or not at Shoa Robit and neighboring rural kebeles. However, the relative disinfection efficiency varies with the following order; treatment using mirrors $>$ aluminum foil $>$ treatment without activators.
\end{abstract}

Copy Right, IJAR, 2018,. All rights reserved.

\section{Introduction:-}

During the last decades waterborne diseases have taken the world leading killer. There are 3.575 million deaths each year from water-related disease, and $98 \%$ of these occur in developing countries [1]. To overcome this adverse effect point-of-use (POU) water treatment technologies have received increasing attention as valuable tools for improving drinking water quality [2-4]. Chemical disinfection, membrane filters, thermal technologies, coagulation and solar water disinfection (SODIS) are common POU water treatment technologies. Among all SODIS due to low cost and ease of use have received a huge interest for disinfection microbes from polluted water. This simple pointof-use treatment can be utilized to create safe drinking water in rural areas of developing countries and in emergency situations (wars and natural disasters) [5]. It consists of exposing a bottle of biologically contaminated water to direct sunlight, allowing the ultraviolet (UV) component of the light to energize reactions in the water that kill or inactivate microorganisms [6-7].

The UV light that reaches the earth's surface is mainly in the UV-A and UV-B regions, which consist of the wavelengths from 280-315 nm and 315-340 nm, respectively. This part of the light is capable of disinfecting water. The $200-300 \mathrm{~nm}$ wavelengths can be absorbed by DNA and RNA, fusing thymine or uracil base pairs and causing mutations that inhibit reproduction [8]. Solar intensity varies with location, time of day, season, weather conditions, and many other factors. Average intensity levels in the areas near the equator get the most direct sunlight; it is generally recommended that SODIS be used with the latitude range from $35 \mathrm{~N}$ to $35 \mathrm{~S}$ [9]. Most of developing regions of the world lie in these latitudes, which is where low cost water treatment is most needed. 
However, the potential of natural solar radiation disinfection at different parameters are not fully defined. UV absorbing organics and turbidity are the sources of potential interference for SODIS technique. Besides, the dependence of SODIS on latitude, altitude, and geographic factors on disinfection potential has not been systematically documented. Therefore, in this paper we report a facile and enhanced disinfection of biological contaminated water using natural solar radiation. The enhanced disinfection efficiency of SODIS was investigated at different activation agents, including aluminum foil and mirror. $\mathrm{pH}$ and turbidity of water was also studied.

\section{Materials and methods:-}

\section{Source of water samples:-}

Shewa Robit is a town in north-central Ethiopia. Located in the Semien Shewa Zone of the Amhara Region, has a longitude and latitude of $10^{\circ} 06^{\prime} \mathrm{N} 39^{\circ} 59^{\prime} \mathrm{E} / 10.1^{\circ} \mathrm{N} 39.983^{\circ} \mathrm{E}$ with an elevation of 1280 meters above sea level. The water sample was collected from Shoa-Robit municipal water and surrounding rural kebeles (Abay Atir and Ashale ponds) two times during the period from April, 2012- May,2012, and Augest,2012 - September, 2012. A volume of $8 \mathrm{~L}$ of water was collected in sterile plastic bags. Samples were kept in ice box during transfer and processed after transportation at DBU Chemistry and Biology laboratories. Temperature of water was recorded immediately in the field, while $\mathrm{pH}$, the conductivity, the alkalinity and coliform were sent to DBU.

\section{Sampling procedure:-}

The technique used for sampling from wells was according to the procedure described by WHO. Then water sample was divided into five groups (each $1.5 \mathrm{~L}$ ) and then exposed to solar radiation on the roof ( without activator), with mirror, and with aluminum foil at the research are for the period of 6 hours, but during this period and every each hour, water sample was taken from each group for culturing to estimate the reduction in the bacterial concentration due to exposure to sunlight. After arriving in the laboratory water samples were cultured on different media at a starting time (zero time), to estimate the bacterial counts of water samples.

\section{pH analysis of the water:-}

Measurement of $\mathrm{pH}$ is one of the most important and frequently used tests, as every phase of water and wastewater treatment and waste quality management is $\mathrm{pH}$ dependent. $\mathrm{pH}$ value is governed largely by the carbon dioxide/ bicarbonate/ carbonate equilibrium. The effect of $\mathrm{pH}$ on the chemical and biological properties of liquid makes its determination very important. Here it was measured by a pH meter (pH meter 340i/SET, WTW 82362 Weilhim).

\section{Microbiological examination of water samples:-}

Microbiological examinations were performed to determine the Total Coliform (TC). The original sample, $0.1 \mathrm{ml}$ was directly pipetted into the surface of the prepared agar plates and distributed all over using a sterile L-shaped glass loop. The plates were incubated at $35^{\circ} \mathrm{C}$ for 24 to $48 \mathrm{~h}$. The colonies will form on the surface of the agar plate from both original and diluted samples were counted using Quebec Colony Counter and recorded as CFU/ml.

\section{Statistical analysis of the efficient of various reflectors and sunlight only:-}

The relative disinfection efficiency of SODIS method with mirror, aluminum foil, and without reflector as well as contact time was analyzed their significances by Analysis of Variance (ANOVA) model.

\section{Result and Discussion:- pH of water:-}

$\mathrm{pH}$ of water expresses the concentration of the acid or alkaline condition of a solution. It is one of the most important operational water quality parameters, the optimum $\mathrm{pH}$ required often being in the range 6.5-9.5. However, the drinking water use in Shoa Robit $(\mathrm{pH} \sim 7.4)$ and Rasa kebeles $(\mathrm{pH} \sim 7.2-7.8)$ which is close resemble to the standard WHO water quality parameter [10].

\section{Turbidity test:-}

The water turbidity is main factor to SODIS water treatment method. If the water is very turbid, the effective of the method is reduced. It was used a facile Nuephelometric method to investigate the turbidity of water samples. The filled PET bottle must be placed on the top of the newspaper head line. Now one must look at the bottom of the bottle from the neck at the top and through the water. If the head line of the paper is readable, the water can be used. The turbidity of Shoa Robit municipal drinking water is much clear than Rasa Kebeles drinking waters. This High 
level of turbidity can protect microorganisms from the effects of disinfection, stimulate the growth of bacteria and decrease the potential of solar radiation to disinfect microbes.

\section{Microbe disinfection study:-}

The impacts of natural solar radiation on the inactivation of bacterial coliform was investigated. The effect of mirror and aluminum foil compared with the absence of activator was tested as well as the duration of sunlight was tested.

The disinfection efficiency SODIS at various contact time in Shoa Robit town:-

The disinfection efficiency of natural solar radiation at different hours were investigated. At the end of one-hour disinfection efficiency of SODIS was recorded as shown in Table. 3.1

Table 3.1:- The total coliform concentration count at Shoa Robit at the end of one hour with mirror, aluminum foil and without activator.

\begin{tabular}{|l|l|l|l|}
\hline Without Activator & With Mirror & With Aluminum Foil & Control \\
\hline 1750 & 1210 & 1400 & 5320 \\
\hline 970 & 1200 & 1765 & 5340 \\
\hline 1830 & 1300 & 1340 & 7670 \\
\hline 1870 & 1600 & 1570 & 4780 \\
\hline 1650 & 1700 & 1680 & 6540 \\
\hline 1400 & 1340 & 1700 & 5900 \\
\hline 7800 & 1700 & 1670 & 6230 \\
\hline 1400 & 1900 & 1570 & 5800 \\
\hline
\end{tabular}

The analysis of variance (ANOVA) at the end of one hour (Table. 3.1) has clearly indicated that the null hypothesis can be rejected for the statement "all treatments are the same"; the Fobs value is 24.24 , which is much greater than the Fcrit. value, 2.95 .

The analysis of variance (ANOVA) for time one hour

\begin{tabular}{lccccc}
\hline \multicolumn{1}{c}{ Source } & df & SS & Mean square & $\mathbf{F}_{\text {obs }}$ & $\mathbf{F}_{\text {crit }}(\mathbf{3 ; 0 . 0 5 )}$ \\
\hline $\begin{array}{l}\text { Treatment } \\
\text { agents }\end{array}$ & 3 & 106364446.1 & 35454815.36 & 24.2400801 & 2.95 \\
$\begin{array}{l}\text { Within } \\
\text { treatments }\end{array}$ & 28 & 40954271.88 & 1462652.567 & & \\
\end{tabular}

Total 
Table. 3.3:- The least significant difference (LSD)

\begin{tabular}{lcc}
\hline Term & constant & Value \\
\hline \# of treatment & $\mathrm{K}$ & 4 \\
required \# of tests & $\mathrm{c}=\mathrm{k}(\mathrm{k}-1) / 2$ & 6 \\
overall level of significance & $\mathrm{b}$ & 0.05 \\
& $\alpha=\mathrm{b} / \mathrm{c}$ & 0.00833333 \\
level of significance & $\mathrm{MSD}$ & 1462652.57 \\
mean square & & 8 \\
average no. of sample size(n) & $(2(\mathrm{MSE}) / \mathrm{n})^{1 / 2}$ & 604.70087 \\
standard error for two means (s.e.) & & 2.467 \\
& $\mathrm{t}_{28,0.01}$ & \\
t-static & & 1491.79705 \\
& & \\
LSD & &
\end{tabular}

The least significant difference (LSD) was also calculated as shown in Table 3.3. The number of treatment agents (k) was four. The number of required experiments (c) was six. To achieve an overall confidence interval of $95 \%$ (b), the experiments were performed at a significance level of $99 \%(\alpha)$. To calculate the LSD, the standard error of the difference

LSD = s.e. $\left(t_{28,0.01}\right)=1491.79705$

Therefore, the averages TC concentrations (Table 3.4) for the bottles disinfected with mirror and other treatment as compared with control is larger than the LSD (1491). Hence, the treatment either of methods for one hour makes statically different output. But, there is no significant statically differences between the treatment methods with one hours.

Table 3.4:- Average TC concentration at the end of one hour

\begin{tabular}{lc}
\hline Treatment & Average coliform \\
\hline Without activator & 2333 \\
With mirror & 1493 \\
With aluminum foil & 1586 \\
Control & 5947 \\
\hline
\end{tabular}

Besides, analysis of variance for the disinfection efficiency of SODIS at the end of six hours was calculated as shown Table 3.5. It shows that the null hypothesis cannot be rejected for the 
Table 3.5:- The analysis of variance of different treatments at Shoa Robit at the end of six hours

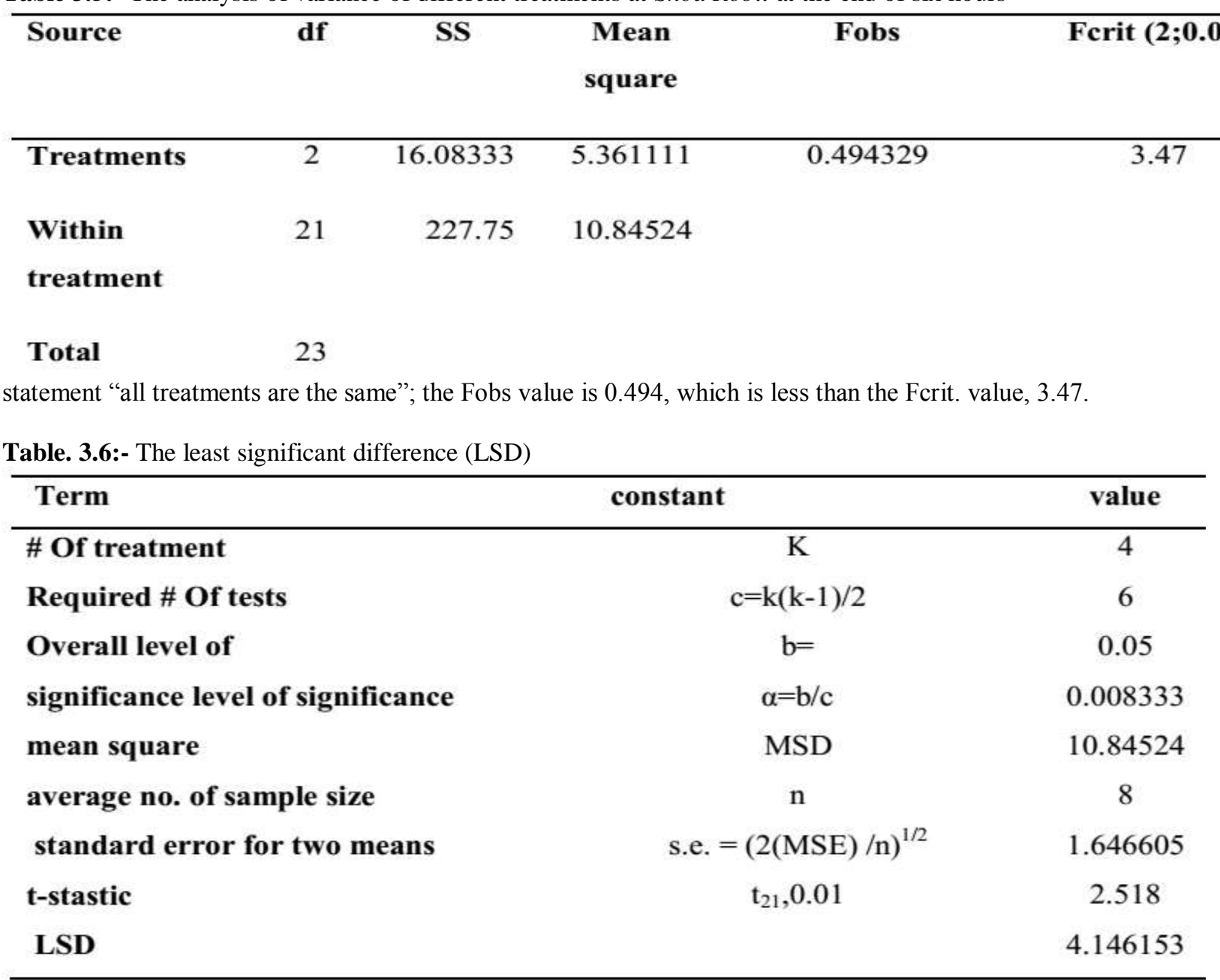

The obtained LSD (Table 3.6) is LSD $=$ s.e. $\left(\mathbf{t}_{\mathbf{2 1}, 0.01}\right)=\mathbf{4 . 1 4 6}$. The difference between the average coliform concentrations (Table 3.7) for the bottles disinfected by solar radiation without activator and with activators including mirror and with aluminum foil is smaller than the LSD (4.15). Hence, the treatment either of methods (with mirror and with aluminum foil) as well as treatment without any activator did not bring statistical different at the end of six-hour period.

Table 3.7:- Average TC concentration at the end of one hour at Ashal Kebele

\begin{tabular}{lc}
\hline Treatment & Average coliform \\
\hline Without activator & 7 \\
With mirror & 5 \\
With aluminum foil & 6 \\
\hline
\end{tabular}

In general, the relative disinfection efficiency of SODIS as a function of time as shown in Figure 3.1, the disinfection efficiency of natural solar radiation with increasing the contact time. 


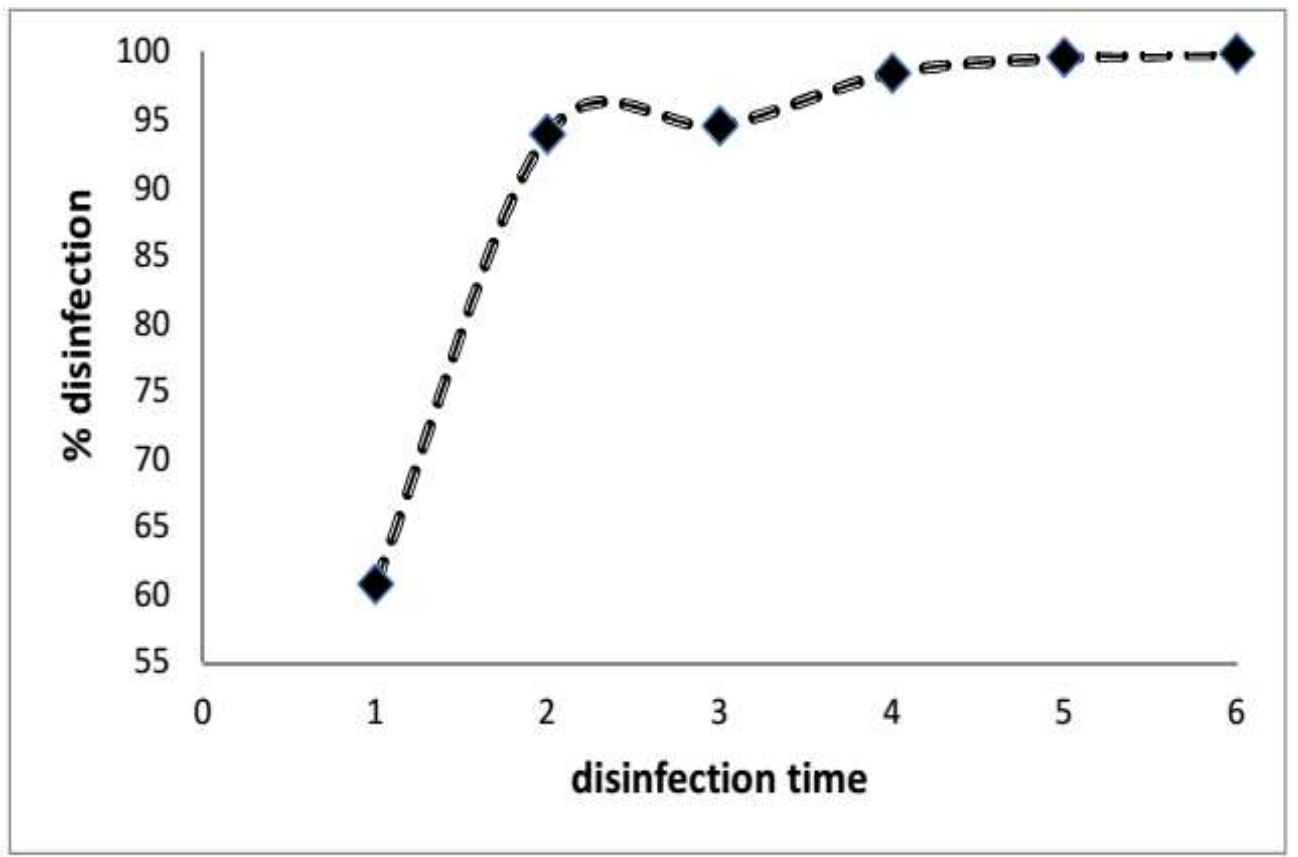

Figure 3. 1:- The disinfection efficiency of natural SODIS at Shoa Robit

The disinfection efficiency SODIS at various contact time at Ashal kebele:-

The disinfection efficiency of SODIS at the end of one hour is presented in Table 3.8. The analysis of variance (ANOVA) at the end of one hour was determined to check the significance in deference between SODIS treatment of water with and without activators. The results were shown that all SODIS treatment of water at different activators will bring different degree of disinfection at the end of one hour.

Similarly, the disinfection efficiency of SODIS was investigated at different hours. At the end of six hours, SODIS have strong efficiency to disinfect the microorganism. The table below shows the analysis of variance (ANOVA) for time six hours as shown in Table 3.9, ANOVA table at the end of six hours, the null hypothesis cannot be rejected for the statement "all treatments are the same"; the Fobs value 0.64, which is less than the Fcrit. value, 3.47.

Table 3. 8:- The total coliform concentration count at Ashal at the end of one hour with mirror, aluminum foil and without activator.

\begin{tabular}{cccc}
\hline Without Activator & With Mirror & $\begin{array}{c}\text { With Aluminum } \\
\text { Foil }\end{array}$ & Control \\
\hline 80000 & 78000 & 60000 & 500000 \\
75000 & 72000 & 75000 & 534000 \\
83400 & 63000 & 73400 & 767000 \\
83700 & 68700 & 53700 & 478000 \\
65700 & 60700 & 68700 & 654000 \\
75400 & 73400 & 70000 & 590000 \\
78700 & 83700 & 68700 & 623000 \\
69700 & 79700 & 59700 & 580000 \\
\hline
\end{tabular}


Table 3.9:- The analysis of variance of different treatments at Ashal kebele at the end of six hours

\begin{tabular}{cccccc}
\hline source & df & SS & mean square & Fobs & Fcrit \\
\hline Treatments & 2 & 10.19444444 & 5.097222222 & 0.64001 & 3.47 \\
$\quad$ within & 21 & 167.25 & 7.964285714 & & \\
$\begin{array}{c}\text { treatments } \\
\text { total }\end{array}$ & 23 & & & & \\
\hline
\end{tabular}

The average coliform concentrations for treatments within six hours are found in Table 3.10. The difference between the average coliform concentrations for the bottles cleaned by SODIS without no activator and the other treatment, with mirror and with aluminum foil averages is smaller than the LSD (3.55). Hence, the treatment either of methods (with mirror and with aluminum foil) as well as treatment without any activator for six hours makes not statistical different. Figure 3.2 is presented the disinfection efficiency of natural solar radiation disinfection increases with increasing contact time.

Table 3.10:- Average TC concentration at the end of six hours at Ashal kebele

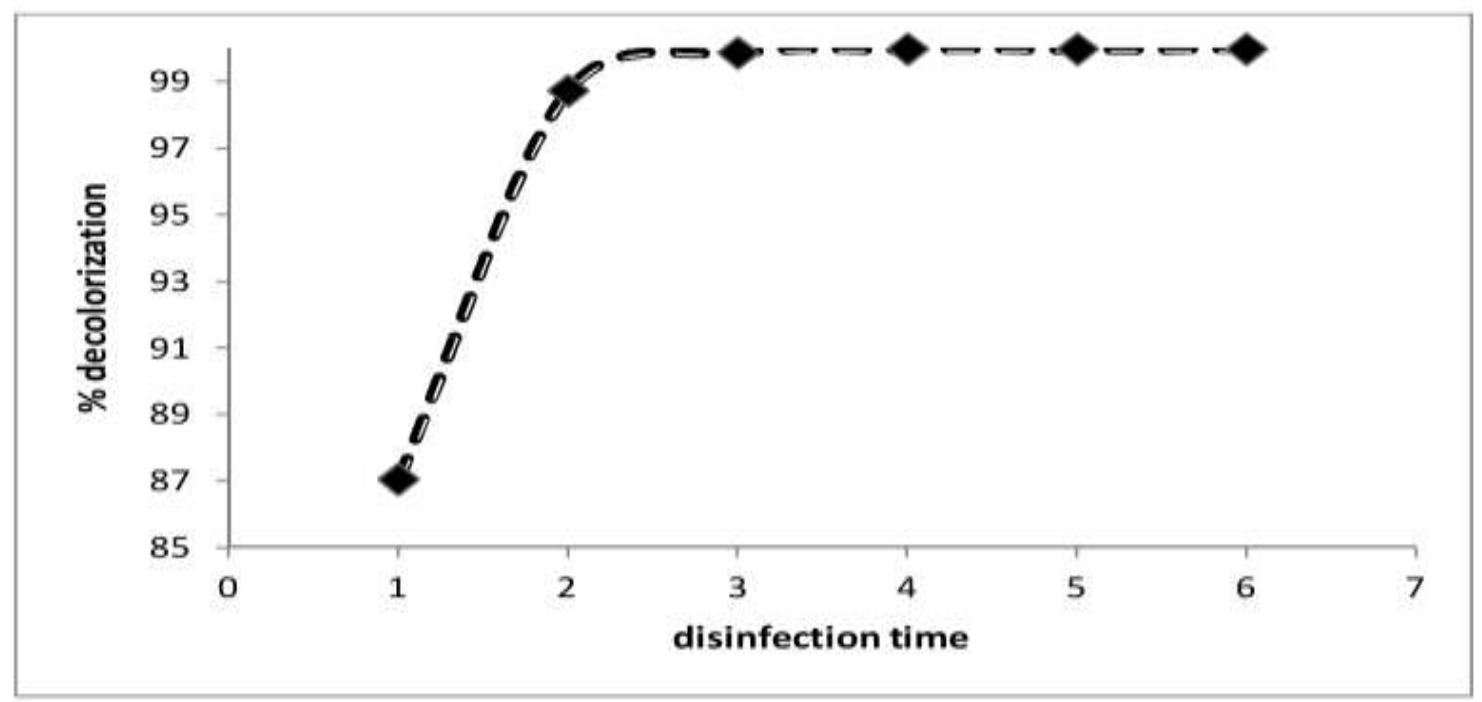

Figure 3.2:- The disinfection efficiency of natural SODIS at Ashal kebele

\section{Conclusion:-}

In conclusion, the disinfection of river and pond water for potable purpose using SODIS vary with different activators. The use of mirrors and aluminum foils increases significantly the efficiency of solar treatment of water and improves the quality of water in a shorter time compared with treatments without any activators. Exposure time 
of the sample with solar radiation in the first three hours brought a significant effect however the time goes at the end of five and six hours treatment with mirror, aluminum foil and without activator have not significant difference. At the end of six hours almost $99.9 \%$ of the water disinfected effectively.

\section{Acknowledgments:-}

The authors kindly acknowledge to the Debre Birhan University for financial support.

\section{References:-}

1. WHO, 2009. Death and Disability-adjusted Life Year (DALY) Rates, by WHO Region. World Health Organization.

2. Mintz, E., Bartram, J., Lochery, P., Wegelin, M., 2001. Not just a drop in the bucket: expanding access to pointof-use water treatment systems. Am. J. Public Health 91 (10), 1565-1570.

3. Clasen, T., Haller, L., Walker, D., Bartram, J., Cairncross, S., 2007. Cost-effectiveness of water quality interventions for preventing diarrhoeal disease in developing countries. J. Water Health 5 (4), 599-608.

4. Acra A., Karahagopian Y., Raffoul Z., and Dajani R.,1980. Disinfection of Oral Rehydration Solutions By Sunlight. The Lancet, 2: 1257-1258.

5. Michael B. Fisher, Mercedes Iriarte, Kara L. Nelson., 2012. Solar water disinfection (SODIS) of Escherichia coli, Enterococcusspp., and MS2 coliphage: Effects of additives and alternative container materials ,water research 46, 1745-1754.

6. McGuigan, K.G., Joyce, T.M., Conroy, R.M., Gillespie, J.B., Elmore-Meegan, M., 1998. Solar disinfection of drinking water contained in transparent plastic bottles: characterizing the bacterial inactivation process. J. Appl. Microbiol. 84 (6), 1138-1148.

7. Rincón, A.G., Pulgarin, C., 2004. Field solar E. coli inactivation in the absence and presence of $\mathrm{TiO}_{2}$ : is UV solar dose an appropriate parameter for standardization of water solar disinfection? Sol. Energy 77 (5), 635648.

8. Oates, P.M., Shanahan, P., Polz, M.F., 2003. Solar disinfection (SODIS): simulation of solar radiation for global assessment and application for point-of-use water treatment in Haiti. Water Res. 37 (1), 47-54.

9. Kevin G. McGuigana, Ronán M. Conroya, Hans-Joachim Mosler, Martella du Preez, Eunice Ubomba-Jaswac, Pilar Fernandez-Ibã nez., 2012. Solar water disinfection (SODIS): A review from bench-top to roof-top, Journal of Hazardous Materials, 29- 46.

10. WHO 2011, fourth ed., Guidelines for Drinking Water Quality. 